\title{
Green finance and the economic threats during COVID-19 pandemic
}

\author{
Dalia Streimikiene \\ Mykolas Romeris University, Vilnius, Lithuania, e-mail: dalia@mail.lei.lt \\ Vitaliy Kaftan
}

Financial University under the Government of the Russian Federation, Moscow, Russia, e-mail: VVKaftan@fa.ru

Citation: Streimikiene, D., Kaftan, V. (2021). Green finance and the economic threats during COVID-19 pandemic. Terra Economicus 19(2): 105-113. DOI: 10.18522/2073-66062021-19-2-105-113

Our paper aims at describing the links between green finance and sustainable development in the light of the environmental threats and natural disasters represented by the recent coronavirus pandemic caused by the COVID-19 virus. The recent situation heavily impacted on the financial and banking system and transformed the way it has functioned before. Moreover, it demonstrated that the banking system is more vulnerable than it should be. The banking sector has shown little capacity to absorb unexpected risks, owing to far-reaching international financial reforms. There are indications that some banks are on the verge of collapse, while some non-bank financial institutions and markets need immediate support. A decade after the financial crisis, the world is still struggling with the problems posed by the events of 2007-2009. Moreover, decisions taken during the crisis increased the risk that pandemic financial stress would develop into a banking crisis over time. Our paper shows that now there is a need for the creation of healthy environment marked by the carbon-free and environmentallyfriendly approaches, and the green finance might help us to achieve that goal. Our results make it clear that by promoting such instruments as green bonds, green loans and green mortgages stakeholders and policy-makers might help to create a more sustainable future for the people, their natural environment, and the economy as a whole.

Keywords: green finance; economic systems; sustainable development; institutional change; COVID-19; banking and finance

JEL codes: $M 31,044,056,059$

(ㄷ Д. Стреймикиене, В. Кафтан, 2021 


\title{
Финансирование экологичньх проектов и экономические угрозы во время пандемии COVID-19
}

\author{
Далия Стреймикиене \\ Университет Миколаса Ромериса, Вильнюс, г. Литва, e-mail: dalia@mail.lei.lt \\ Виталий Кафтан \\ Финансовый университет при Правительстве РФ, г. Москва, Россия, e-mail: VVKaftan@fa.ru
}

\begin{abstract}
Цитирование: Streimikiene, D., Kaftan, V. (2021). Green finance and the economic threats during COVID-19 pandemic. Terra Economicus 19(2): 105-113. DOI: 10.18522/2073-66062021-19-2-105-113
\end{abstract}

Наша статья описывает связи между «зелёным» финансированием и устойчивым развитием в свете экологических угроз и стихийных бедствий, представленных недавней пандемией коронавируса, вызванной вирусом COVID-19. Недавняя ситуация сильно повлияла на финансовую и банковскую систему и изменила те правила, по которым она функционировала раньше. Более того, пандемия продемонстрировала, что банковская система более уязвима, чем должна быть, к подобым типам кризисов. Банковский сектор продемонстрировал небольшую способность принимать на себя неожиданные риски из-за далеко идущих изменений в международной финансовой сфере. Спустя десятилетие после финансового кризиса мир все еще борется с проблемами, вызванными событиями 2007-2009 г2. Более того, решения, принятые во время кризиса, увеличили риск того, что финансовый стресс, обусловленный пандемией, со временем перерастет в новый мировой экономический кризис. Пандемия COVID-19 выявила уязвимые места финансовой системы и вынудила центральные банки и правительства внимательнее изучить уроки финансового кризиса, которые могут быть полезны для экономической и финансовой политики, способны заложить новую институциональную основу для посткризисных экономических систем. Наше исследование показывает, что на сегодняшний день существует потребность в создании здоровой окружающей среды, отмеченной безуглеродными и экологически безопасными подходами, и «зеленое финансирование» может помочь в достижении этой цели. Наши результаты ясно показывают, что, продвигая такие инструменты, как «зеленые» облигации, «зеленые кредиты» и «зеленая ипотека», заинтересованные стороны и лица, определяющие политику, могут способствовать достижению целей устойчивого развития.

Ключевые слова: зеленые финансы; экономические системы; устойчивое развитие; институциональные изменения; COVID-19; банковское дело и финансы

JEL codes: $M 31,044,056,059$

\section{Introduction}

A sustainable financial system is one that creates and transacts financial assets which shape real prosperity in a way that serves the interests of people, the environment, and the economy as a whole, not just the rich. Green finance refers to financial instruments whose proceeds are used to promote sustainable, environmentally friendly financial systems such as green bonds, green loans and green mortgages (Flammer, 2020; Katona, 2020). The two main objectives of green finance are to internalize environmental externalities and reduce risk perception, both in financial markets and in the wider economy. With changing environmental policies, low costs - carbon technologies are becoming cheaper and consumers are seeking less choice - the world is rapidly turning away from fossil fuels, 
as technological developments make change even more financially attractive, and policymakers do a lot - necessary steps to make the economy greener (Khoshnava et al., 2019; Chen et al., 2021). This transition is taking place despite the fact that the fossil fuel industry has been in financial difficulty for years, but it is accelerating because technological development is making this change even more difficult to push away and squeezing out even tougher efforts (Bos, Gupta, 2019). When the Paris Agreement was signed, few could have predicted how quickly consumer demand, investor sentiment, and regulation would put climate change and its sustainability at the top of so many industries' agendas (Geden et al., 2018). For example, investors in the United States secure a shareholder proposal that requires each of the leading banks to fully disclose fossil fuel financing (Griffin, Myers Jaffe, 2018).

The financial sector plays a crucial role in the transition to a more sustainable future, but it is not the only sector that plays a role (Č́belková et al., 2020). The influence of financial institutions as financial services providers means not only that they control their own impact on companies, but also that they do more than any other industry to integrate global business and investment (Štreimikienè et al., 2016; Lisin et al., 2018; García-Sánchez et al., 2020; or Štreimikienè et al., 2020). Sustainable finance generally refers to a more proactive approach to investment decisions, which leads to increased long-term investment in renewable energy, energy efficiency and sustainability. More specifically, it can refer to environmental aspects, but also to the environmental and human health effects of financial transactions. It can, for example, relate to social considerations, to the impact of financial transactions on the environment, human health and the economy as a whole. Capital markets can play a critical role in addressing this gap by redirecting capital toward sustainable investment, addressing the financial risks of climate change, and promoting transparency and long-term sustainability. Liquidity providers can facilitate the transition to sustainable investment by providing liquidity to its products and making these products more accessible to end customers - investors who want to invest (Louche et al., 2019). Corporations such as Optiver Europe aim to help reflect on what the next steps for green financial and financial policy should be in Europe and globally, according to a recent report by the European Commission's Office for the Coordination of Economic and Social Affairs (Optiver, 2020). This can be done by narrow supply spreads - question spreads and the presentation of volumes that contribute to a deep liquid market - and by providing liquidity for ESG products in the form of short- and medium-term contracts. On the other side of the world, China's boost to the green bond market comes at a time when momentum is already building. As new issuers enter the market and institutional investors become more aggressive in seeking ways to hedge their climate risk, demand and supply for green investments are growing rapidly (Deschryver, De Mariz, 2020).

Today, green bonds are the second-largest investment vehicle in the United States market, just after equities. Globally, green finance is transforming into mainstream investments to generate safe and effective returns, protect portfolios from climate risks, and finance sustainable growth (Faske, 2018). Transparency is at the heart of a good financial market and a reliable benchmarking system that assesses the sustainability aspects of investments as rigorously as the financial aspects could be crucial for economies like China that seek sustainable growth. Ensuring that green bonds and other green financial investments fit into the global financial system probably requires greater transparency about the expected climate impact of investors' assets, as well as a more transparent and clear investment process. Although green bonds can meet some of these goals, work remains to industrialize green finance and essentially create a global market for green investments, such as green equity, green debt, or green equities (Bolton et al., 2020).

In 2016, France adopted a comprehensive climate law that included the first mandate for investor climate reporting, and other countries, including India and Mexico, have recently adopted green bond frameworks. The G20 issued a statement calling for the development of a green finance economy and launched the Green Finance Study Group, which produces international standards and indicators to assess the impact of a green finance economy (Fues, 2020). After the Hangzhou summit, the People's Bank of China issued guidelines for countries' green finance industries. The next step is to develop a system for assessing and evaluating industrial strength, which will provide investors 
and issuers with consistent, rigorous and transparent methods for assessing green issues. In December 2016, the World Bank's Global Green Finance Initiative (GFI), the world's largest climate-related financial information authority, published its first guidelines for financial and non-financial companies covering climate and energy, energy efficiency, renewable energy and environmental protection, and sustainability to cover non-financial firms.

This paper is structured as follows: Section 2 describes the issue of green finance and environmental threats. Section 3 analyses the impacts and outcomes of the COVID-19 pandemic on the financial industry. Section 4 tackles the role of the green finance in the post-pandemic recovery. Finally, the Conclusions and implications section closes this paper and offers some insights and perspectives of this research.

\section{Green finance and environmental threats}

The Green Finance strategy aims to establish a common understanding of "greening", clarify the role of finance as a key component of the greening of our economy and establish a common framework for the development of a sustainable financial system. It is also important that the sector can demonstrate its social objectives (Migliorelli, 2021).

More recently, many financial institutions and companies have been more concerned about the need to meet the net emissions target of zero carbon emissions by 2050. This includes internalizing external environmental factors and adapting risk perception to encourage environmentally friendly investments and reduce polluting ones (Shahbaz et al., 2020). For example, it is important that we behave responsibly in our decisions on how to reduce energy consumption and restrict business travel. Promoting large-scale, economically viable green finance helps to prioritise green investment over - as usual - business investment that supports unsustainable growth patterns. According to some estimates, Asia's developing countries will need to invest $\$ 1.7$ trillion annually in infrastructure between 2016 and 2030. The focus can be on greening existing infrastructure spending and mobilizing new investments in renewable energy, energy efficiency and energy efficient technologies (Nassiry, 2018; Strielkowski et al., 2019).

Central banks and financial supervisors could be a key player in developing climate finance instruments that can help reduce systemic risk and stranded assets. Other arguments in favour of an expanded role for central banks and financial supervisors in climate finance include the need to develop a long-term national strategy. Given that climate change is becoming a major threat to the global economy, central bank supervisors should be asked to analyse its effects and intervene to fulfil their duties as public institutions. If their responsibilities include restricting certain types of lending, they should limit financial flows to carbon-intensive and polluting borrowers, in order to mitigate credit market failures (Lu et al., 2019). This includes the use of credit-to-debt mechanisms for investment to encourage the development of green projects and minimise the impact of more regular projects on the climate (Clark et al., 2018). The environment teams are already working with public and private sector organizations to align the international financial system with the Sustainable Development Agenda. The United Nations Environment Agency has been involved in a number of efforts to rebalance regulatory frameworks, for example, to make green borrowing compliant, and to shift public-sector planning in greener directions. This includes the use of green financing mechanisms such as green bonds and green loans, and the development of a global framework for green finance. The success of the United Nations Sustainable Development Goals (SDGs) will depend on well-implemented green financing solutions that will also bring benefits to enhance overall corporate sustainability and positively affect the environment, human health and the health of the global economy as a whole. According to many authors and their studies, green finance can be linked to the majority of SDGs, but the financial system has the capacity to adapt and develop innovative direct finance mechanisms to meet economies' development needs, while providing financial resources to address the need for financial efficiency (Batrancea et al., 2020). Green finance research is crucial to support a more efficient and sustainable financial and economic system that benefits not only the economy but also the public and private sectors. 


\section{COVID-19 pandemic and the financial industry}

Banks have certainly had to act since the outbreak of COVID-19, and as the virus continues to spread around the world, borrowers and businesses are facing falling sales and profits, as well as higher interest rates and higher costs (Wójcik, Ioannou, 2020). Bank customers are likely to seek financial relief, and the United States Federal Reserve and financial authorities in other countries are encouraging banks to help them. To deal with the direct economic impact of coronavirus, banks must have plans to protect employees and customers from its spread. Closures to prevent the spread of COVID-19 virus have brought economic activity to a standstill in many sectors, with significant implications for businesses and households (Strielkowski et al., 2021). Companies that rely on selling goods and services such as restaurants, hotels and retail outlets have lost revenue streams. Households working in these sectors have also lost employment and income as a result of the closure of their businesses. The negative effects of the COVID-19 crisis have also spread to banks and other financial institutions, because banking services can be provided remotely and do not rely on direct customer contact. At the same time, the banking sector has played an important role in triggering the need to support businesses and households in times of low income (Liu et al., 2002).

Banking systems in Europe and the United States must play a role in getting the economy back on track after the pandemic by lending to businesses that have suffered. However, how effective their support for economic recovery will be depends on the resilience and health of the banks. The loss of risk-weighted assets, such as derivative assets, will eat up banks' capital and reduce their liquidity. This vulnerability could have an increasing impact on the supply and financing of the real economy in general. The outcome is likely to increase vulnerability in the non-financial sector, but the necessary government containment measures will lead to a return to a more stable financial system and thus to a stronger economic recovery. Banks were asked to support a government-led programme of providing emergency loans with permanent liquidity through credit facilities (Didier et al., 2021).

As corporate and household debt continues to rise, so will risks in the banking sector, including the risk of credit default swings and the potential for further increases in borrowing costs. Central banks have aggressively cut interest rates further from their historic lows, putting additional pressure on banks' interest-rate margins. Although central banks focus on financing companies, they have also chosen to emphasize the risk of bank resolution that developed during the global financial crisis. The liquidity problems of households, companies and public sector organisations, which led to banks not lending after the 2008 financial crisis, plunging the international financial system and the global economy into a vortex of financial and economic crisis, and the collapse of Lehman Brothers in 2009 (Rahman, 2020).

As the global economy struggles to survive this pandemic, the crisis is particularly serious for borrowers who depend on exports to international markets. Financial institutions in almost all countries fear increased risk of defaults aggregate demand for goods and services in their countries slows, unemployment increases, and the number of people without access to credit increases. As a result, banks are likely to see a significant increase in the number of loans to non-United States banks. This is because banks are typically exposed to much higher default risk than other financial institutions, and because they are more closely interconnected. Banks are based on their exposure to COVID-19 and the downside risk associated with it, as well as other risk factors such as the so-called credit default swaps (CDS). The vulnerability of the issuer may also be worsened by the lack of liquidity, as has been the case in some emerging markets. This includes the impact on the banking system and the ability of banks to support public authorities, banking systems and their customers. The short-term effects will be reduced in the long term, laying the foundations for a rapid recovery of economies (Giese, Haldane, 2020; Estevão, 2020).

\section{Green finance and the post-pandemic recovery}

Remarkably, the COVID-19 crisis is not the first time that some economies turned a major economic crisis into a catalyst for inclusive development. Effective management of the COVID-19 pandemic was praised, and a comprehensive national plan to create jobs and green recovery was presented in South 
Korea (Parra et al., 2021). According to the Asian Development Bank (ADB), South Korea must lead a national green growth strategy as part of its long-term economic recovery. This recovery strategy ultimately supports fossil fuels and carbon-intensive investments that deviate from the Paris agreement's target and undo the gains made so far in protecting countries' natural environment. While South Korea's reliance on coal-fuelled energy and other fossil fuels remains a major obstacle for the region's emerging economies to respond to broader demands for a low-carbon transition, there are regulatory developments that are paving the way for increased sustainable finance initiatives. In Southeast Asia alone, an estimated $\$ 1.5$ billion in infrastructure investment is needed annually to adapt to climate change. Closing this gap is crucial for private-sector financing, given a funding gap estimated at $\$ 102$ billion per year for selected Southeast Asian countries (Nepal et al., 2021).

Shortly after the COVID-19 threat emerged, there was a concerted effort to prioritize green financing to focus on the urgency of the pandemic. It changed the financing landscape by dramatically reducing the need to divert government budgets from large emergency programs. As long-term recovery strategies took shape, the crisis was linked to the development of a global strategy to mitigate and adapt to climate change, as well as to economic recovery. In particular, the principles of sustainable finance were enshrined by the European Union, which recently presented its Sustainable Development Goals for the next five years. The global pandemic has set back the continent's growth and required a new approach to economic development. Sustainable finance could help to accelerate global recovery from COVID-19, while providing incentives for much-needed investment in renewable energy and green infrastructure projects (Fan et al., 2021). Passing on funds raised for projects to reduce emissions and mitigate climate impacts can ensure that the resulting economic recovery is mutually reinforcing. Financial experts from around the world and private sector representatives are meeting to discuss how the financial industry can contribute to a long-term economic recovery while pursuing the Sustainable Development Goals. They all agree that during the recovery, we need to look at how fiscal stimulus are linked to positive results of sustainable development (Polukhina et al., 2021). Similar to mainland China, Hong Kong requires all listed companies to report by July on the role of boards in ESG governance and to submit an assessment of the impact of climate change.

In simple terms, COVID-19 showed all importance of sustainable finance for the health and well-being of people and the planet. Where economic recovery is urgently needed, green finance can be a long-term solution especially in regions like the Middle East, Africa, Asia and Latin America. Strategies to restore green finances should consider raising funds from global investors. The global green bond market is growing rapidly, with investors increasingly focusing on green bonds as a long-term investment strategy. Sustainability will be a driving force in green finance in the coming decades (Ansari, Holz, 2020). According to a recent World Bank report, sustainable fixed assets will reach $\$ 30.7$ trillion by 2030 . As financial institutions fight climate change on a global scale, they are being tempted to participate (World Bank, 2020).

The lessons of the 2008 global financial crisis show that long-term investment in stimulus packages is needed. One has to recall the global financial crisis and analyse the role of green finance in the post-green recovery period in order to project this on the current situation with the coronavirus pandemic. In general, pandemics are often seen as a precursor to the impending climate crisis, because even rich countries lacked effective crisis-management tools to restrict the spread of viruses. High levels of government debt will haunt us in the long run, even in a post-green recovery period. Repairing company balance sheets and value chains: advocating the use of green finance to help economic recovery after the current global crisis.

\section{Conclusions and implications}

All in all, given the large amount of capital needed to mitigate the effects of climate change and reduce global greenhouse gas emissions, the need for climate finance is more urgent than ever. The successful transition to a low-carbon economy also requires partnerships that can successfully structure their products, that can absorb a commitment to climate finance. The public sector and civil society play a crucial role in climate finance, but the private sector and investors in particular also 
play a crucial role. Impact investors try to generate positive and measurable social and environmental impacts on financial returns.

Indeed, maintaining low-cost lending to households and businesses, and implementing monetary and fiscal policies, as well as the resilience of the financial system, depends on an operationally effective and robust banking system to ensure it - not only in the absence of a pandemic, but also in its response. The banking sector has emerged from the financial crisis better financed, better capitalised and more resilient than before the crisis. However, the final impact of the crisis on the banking sector will depend on efforts to mitigate its impact on households and businesses. Cross-border European mergers would be particularly positive: they would deepen the banking union, offer greater diversification potential, reduce the link between sovereign banking risks and systemic risks, and thus prevent systemic risks from occurring. Overall, it has enabled us to cushion the initial impact of a shock pandemic and helped to maintain credit flowing into the economy, and thus into banks, which were initially the main source of credit for households, firms and financial institutions during the financial crisis. In the long run, we will need to focus on how to increase the resilience of households and small businesses that have been vulnerable for far too long. The economy should continue to be supported by targeting the most affected companies and population groups. Unlike the 2008 financial crisis, today's economic crisis is not caused by a single person or group of people, but by the failure of the global financial system to take the necessary steps to contain a global pandemic. The failure to respond to the public health crisis is a unique challenge for economic and financial policymakers to find an answer. We are still in the midst of a pandemic, and there is little evidence that congressional or financial regulatory action has worked. This is likely to make them less effective and more vulnerable to future crises such as the one of 2008. The COVID-19 public health emergency poses a unique challenge to financial regulation and future policies in the wake of the global financial crisis and failure to respond to it.

In spite of its negative effects, the COVID-19 crisis is an opportunity for banks in general to make up for the indifference of the past and to prove that they are responding more than ever to the needs of their customers. In a way, COVID-19 crisis is an opportunity for financial intermediaries to change and improve their long-term position. It is time for them to review their strategies and incorporate structural, social and environmental approaches, and to stand up for the interests of their customers, their employees and their communities. The recession of 2008-2010 was triggered by a shock to the banking system, there is no doubt that banks have a role to play. Indeed, the financial system's origins date back to a global financial crisis in the late 1990s and early 2000s. During the crisis of 2007-2009, when the global banking system was one of the factors that caused the economic downturn, banks were able to be part of a solution.

Further research is needed to mobilise the necessary resources, bridge obvious knowledge gaps and make progress in addressing questions on how to close the green finance gap. Public and private funding is urgently needed to address the environmental challenges facing people and the planet. Adapting to clean energy sources and reducing overall energy consumption are therefore crucial to mitigating climate change and achieving the goals of the Paris climate agreement.

\section{Jumepamypa / References}

Ansari D., Holz F. (2020). Between stranded assets and green transformation: Fossil-fuel-producing developing countries towards 2055. World Development 130: 104947. https://doi.org/10.1016/j. worlddev.2020.104947

Batrancea I., Batrancea L., Maran Rathnaswamy M., Tulai H., Fatacean G., Rus M.I. (2020). Greening the financial system in USA, Canada and Brazil: A Panel Data Analysis. Mathematics 8(12): 2217. https://doi.org/10.3390/math8122217

Bolton P., Musca X., Samama F. (2020). Global public-private investment partnerships: A financing innovation with positive social impact. Journal of Applied Corporate Finance 32(2): 31-41. https://doi.org/10.1111/jacf.12403

Bos K., Gupta J. (2019). Stranded assets and stranded resources: Implications for climate change mitigation and global sustainable development. Energy Research \& Social Science 56: 101215. https://doi.org/10.1016/j.erss.2019.05.025 
Čábelková I., Blaginin V., Strielkowski W., Platitsyn A. (2020). Sustainable education: altering the opinions on renewable energy sources. E3S Web of Conferences 208: 09001. https://doi. org/10.1051/e3sconf/202020809001

Chen M., Sinha A., Hu K., Shah M.I. (2021). Impact of technological innovation on energy efficiency in industry 4.0 era: Moderation of shadow economy in sustainable development. Technological Forecasting and Social Change 164: 120521. https://doi.org/10.1016/j.techfore.2020.120521

Clark R., Reed J., Sunderland T. (2018). Bridging funding gaps for climate and sustainable development: Pitfalls, progress and potential of private finance. Land Use Policy 71: 335-346. https://doi.org/10.1016/j.landusepol.2017.12.013

Deschryver P., De Mariz F. (2020). What future for the green bond market? How can policymakers, companies, and investors unlock the potential of the green bond market? Journal of Risk and Financial Management 13(3): 61. https://doi.org/10.3390/jrfm13030061

Didier T., Huneeus F., Larrain M., Schmukler S.L. (2021). Financing firms in hibernation during the COVID-19 pandemic. Journal of Financial Stability 53: 100837. https://doi.org/10.1016/j. jfs.2020.100837

Estevão M. (2020). Climate-smart fiscal policy can foster a lasting economic recovery. One Earth 3(3): 273-276. https://doi.org/10.1016/j.oneear.2020.08.017

Fan S., Teng P., Chew P., Smith G., Copeland L. (2021). Food system resilience and COVID-19-Lessons from the Asian experience. Global Food Security 28: 100501. https://doi.org/10.1016/j.gfs.2021.100501

Faske B. (2018). Turning billions into (green) trillions: Tracking the growth and development of the green bond market in China, France, India, and the United States. Tulane Environmental Law Journal 31(2): 293-325.

Flammer C. (2020). Green bonds: effectiveness and implications for public policy. Environmental and Energy Policy and the Economy 1(1): 95-128. https://doi.org/10.1086/706794

Fues T. (2020). Guardian of the Common Good or National Power Projection? What Role for the G20 in the Global Partnership for Sustainable Development? pp. 101-115. In: J. Whalley, M. Agarwal (eds.) Economics of G20. A World Scientific Reference, vol 2: How Developing Countries can Achieve Sustainable Development Goals. World Scientific. https://doi.org/10.1142/9789811214776_0004

García-Sánchez I.M., Rodríguez-Ariza L., Aibar-Guzmán B., Aibar-Guzmán C. (2020). Do institutional investors drive corporate transparency regarding business contribution to the sustainable development goals? Business Strategy and the Environment, 29(5), 2019-2036. https://doi. org/10.1002/bse.2485

Geden 0., Scott V., Palmer J. (2018). Integrating carbon dioxide removal into EU climate policy: Prospects for a paradigm shift. Wiley Interdisciplinary Reviews: Climate Change 9(4): e521. https://doi.org/10.1002/wcc.521

Giese J., Haldane A. (2020). COVID-19 and the financial system: a tale of two crises. Oxford Review of Economic Policy 36(1): S200-S214. https://doi.org/10.1093/oxrep/graa035

Griffin P.A., Myers Jaffe A. (2018). Are fossil fuel firms informing investors well enough about the risks of climate change? Journal of Energy \& Natural Resources Law 36(4): 381-410. https://doi. org/10.1080/02646811.2018.1502240

Katona K. (2020). Is lack of morality an explanation for the economic and financial crisis? A Catholic point of view. International Advances in Economic Research 26(4): 407-418. https://doi. org/10.1007/s11294-020-09809-w

Khoshnava S.M., Rostami R., Zin R.M., Štreimikienè D., Yousefpour A., Strielkowski W., Mardani A. (2019). Aligning the criteria of green economy (GE) and sustainable development goals (SDGs) to implement sustainable development. Sustainability 11(17): 4615. https://doi.org/10.3390/su11174615

Lisin E., Shuvalova D., Volkova I., Strielkowski W. (2018). Sustainable development of regional power systems and the consumption of electric energy. Sustainability 10(4): 1111. https://doi. org/10.3390/su10041111 
Liu Y., Lee J.M., Lee C. (2020). The challenges and opportunities of a global health crisis: the management and business implications of COVID-19 from an Asian perspective. Asian Business \& Management 19: 277-297. https://doi.org/10.1057/s41291-020-00119-x

Louche C., Busch T., Crifo P., Marcus A. (2019). Financial markets and the transition to a low-carbon economy: Challenging the dominant logics. Organization \& Environment 32(1), 3-17. https:// doi.org/10.1177/1086026619831516

Lu J., Ren L., Yao S., Qiao J., Strielkowski W., Streimikis J. (2019). Comparative review of corporate social responsibility of energy utilities and sustainable energy development trends in the Baltic states. Energies 12(18): 3417. https://doi.org/10.3390/en12183417

Migliorelli M. (2021). What do we mean by sustainable finance? Assessing existing frameworks and policy risks. Sustainability 13(2): 975 . https://doi.org/10.3390/su13020975

Nassiry D. (2018). The role of fintech in unlocking green finance: Policy insights for developing countries (https://www.econstor.eu/handle/10419/190304)

Nepal R., Phoumin H., Khatri A. (2021). Green technological development and deployment in the Association of Southeast Asian Economies (ASEAN) - At Crossroads or Roundabout? Sustainability 13(2): 758. https://doi.org/10.3390/su13020758

Optiver (2020). The role of capital markets in green transition (https://www.optiver.com/insights/ news-articles/the-role-of-capital-markets-in-the-green-transition)

Parra P.Y., Hauenstein C., Oei P.Y. (2021). The death valley of coal-Modelling COVID-19 recovery scenarios for steam coal markets. Applied Energy 288: 116564. https://doi.org/10.1016/j. apenergy.2021.116564

Polukhina A., Sheresheva M., Efremova M., Suranova 0., Agalakova 0., Antonov-Ovseenko A. (2021). The Concept of Sustainable Rural Tourism Development in the Face of COVID-19 Crisis: Evidence from Russia. Journal of Risk and Financial Management 14(1): 38. https://doi.org/10.3390/jrfm14010038

Rahman A. (2020). Currency Democracy: The Theory of Organic Global Monetary. New York: Global Currency Initiative.

Shahbaz M., Nasir M.A., Hille E., Mahalik, M.K. (2020). UK's net-zero carbon emissions target: Investigating the potential role of economic growth, financial development, and R\&D expenditures based on historical data (1870-2017). Technological Forecasting and Social Change 161: 120255. https://doi.org/10.1016/j.techfore.2020.120255

Štreimikienė D., Strielkowski W., Bilan Y., Mikalauskas I. (2016). Energy dependency and sustainable regional development in the Baltic states: A review. Geographica Pannonica 20(2): 79-87. https://doi.org/10.5937/GeoPan1602079S

Štreimikienė D., Strielkowski W., Lisin E., Kurdiukova G. (2020). Pathways for sustainable development of urban heat supply systems. E3S Web of Conferences 208: 04001. https://doi.org/10.1051/ e3sconf/202020804001

Strielkowski W., Firsova I., Lukashenko I., Raudeliūnienė J., Tvaronavičienė M. (2021). Effective management of energy consumption during the COVID-19 pandemic: The role of ICT solutions. Energies 14(4): 893. https://doi.org/10.3390/en14040893

Strielkowski W., Volkova E., Pushkareva L., Streimikiene D. (2019). Innovative policies for energy efficiency and the use of renewables in households. Energies 12(7): 1392. https://doi. org/10.3390/en12071392

Wójcik D., Ioannou S. (2020). COVID-19 and Finance: Market Developments So Far and Potential Impacts on the Financial Sector and Centres. Tijdschrift voor economische en sociale geografie, 111(3), 387-400. https://doi.org/10.1111/tesg.12434

World Bank (2020). Supporting climate business opportunities in emerging markets (https://www. worldbank.org/en/news/feature/2020/05/07/supporting-climate-business-opportunities-inemerging-markets) 